\title{
STATUS GIZI BERHUBUNGAN DENGAN KUALITAS HIDUP LANSIA DI PUSKESMAS JOGONALAN I
}

\author{
Istianna Nurhidayati ${ }^{1}$ Fitri Suciana ${ }^{2}$ Niken Ayu Septiana ${ }^{3}$ \\ ${ }^{1,2,3}$ Program Studi Ilmu Keperawatan STIKes Muhammadiyah Klaten \\ e-mail: istiannanurhidayati@gmail.com
}

\begin{abstract}
ABSTRAK
Lansia didefinisikan sebagai seseorang yang mencapai usia lebih dari 60 tahun dan dimana pada masa ini seseorang akan mengalami kemunduran fisik, mental, dan sosial. Salah satu permasalahan yang terjadi pada lansia adalah masalah fisik yaitu fisik yang mulai melemah. Menurunnya kondisi fisik ataupun fungsi tubuh baik anatomis maupun fungsional dapat menyebabkan berkurangnya status gizi. Status gizi yang kurang atau berlebih akan mempengaruhi kualitas hidup lansia. Tujuan penelitian ini untuk mengetahui hubungan antara status gizi dengan kualitas hidup pada lansia di Puskesmas Jogonalan1.Penelitian ini menggunakan desain kuantitatif korelasi dengan pendekatan cross sectional. Populasi penelitian ini adalah lansia di wilayah kerja Puskesmas Jogonalan 1. Responden penelitian sebanyak 133 responden yang diperoleh dengan menggunakan non probability sampling jenis consecutive sampling yang sesuai dengan kriteria inklusi dalam penelitian. Instrumen pengumpulan data menggunakan pengukuran antropometri dan kuesioner. Analisa data bivariat menggunakan uji kendall's tau. Hasil penelitian menunjukkan status gizi kurang 30,8\%, normal 35,3\%, lebih 33,8\% dan kualitas hidup buruk 52,6\%, kualitas hidup baik 47,4\%. Hasil uji kendall's tau menunjukkan adanya hubungan antara status gizi dengan kualitas hidup pada lansia di Puskesmas Jogonalan 1 ( $p$ value $=0,000<0,05$; $\mathrm{r}=0$,529). Kesimpulan: stastus gizi memiliki hubungan dengan kualitas hidup pada lansia di Puskesmas Jogonalan 1.
\end{abstract}

Kata kunci : Status gizi, Lansia, Kualitas hidup

\begin{abstract}
Elderly is someone who reaches the age of more than 60 years and where at this time a person will experience physical, mental, and social setbacks. One of the problems that occur in the elderly is a physical problem that is physically beginning to weaken. The reduced physical condition or bodily function both anatomically and functionally can cause a decrease in nutritional status. Poor or excessive nutritional status will affect the quality of life of the elderly. The aim of this reserch was to determine the correlation between nutritional status with quality of life in the elderly at Public Health Care Jogonalan1. This research used quantitative correlation with cross sectional approach. Population this research was elderly who have their health checked at the Jogonalan 1 Public Health Center. The sample in this study were 133 respondent were obtained by non probability sampling type consecutive sampling with the criteria inclusions. Data collected by instruments using anthropometric measurements and questionnaires. Bivariate data analysis uses the Kendall's tau. The results showed that the nutritional status was $30.8 \%$ less, $35.3 \%$ normal, more $33.8 \%$ and poor quality of life $52.6 \%$, good quality of life $47.4 \%$. The study's result of calculations with the statistical test using the kendall tau test in p-value 0,04. The results of study indicate that there were a significant correlation between nutritional status with quality of life in the elderly. Strength of correlation $(r=0.529)$. Conclusion: Nutritional status has a relationship with quality of life in the elderly at Public Health Center Jogonalan 1.
\end{abstract}

\section{Keywords: Nutritional status, Elderly, Quality of life}




\section{LATAR BELAKANG}

Lansia adalah seseorang yang telah mencapai usia 60 tahun ke atas, menua bukanlah suatu penyakit, tetapi merupakan proses yang berangsur-angsur mengakibatkan perubahan kumulatif, merupakan proses menurunnya daya tahan tubuh dalam menghadapi rangsangan dari dalam dan luar tubuh (Khofifah, 2016). Data dari World Population Prospects (2015) menjelaskan ada 901 juta orang berusia 60 tahun atau lebih, yang terdiri atas $12 \%$ dari jumlah populasi Dunia. Pada tahun 2015 sampai 2030, jumlah orang berusia 60 tahun atau lebih diproyeksikan akan tumbuh sekitar 56\% dari 901 juta menjadi 1,4 milyar, dan pada tahun 2050 populasi lansia diproyeksikan lebih 2 kali lipat di tahun 2015, yaitu mencapai 2,1 milyar (United Nations, 2015).

Peningkatan jumlah penduduk lansia ini akan membawa dampak terhadap berbagai kehidupan. Dampak utama peningkatan lansia ini adalah peningkatan ketergantungan lansia. Ketergantungan ini disebabkan oleh kemunduran fisik, psikis dan sosial lansia yang digambarkan melalui empat tahap, yaitu kelemahan, keterbatasan, kemunduran fungsional, ketidakmampuan dan keterhambatan yang akan dialami bersamaan dengan proses kemunduran akibat proses menua. Dampak proses kemunduran akibat proses menua juga akan mempengaruhi kualitas hidup lansia (Riyanti dan Ratnawati, 2015). Meningkatnya kuantitas lansia tersebut harus diimbangi dengan peningkatan kualitas hidup lansia, selain dapat berumur panjang, lansia diharapkan agar dapat hidup sehat, produktif, dan mandiri sehingga tidak menjadi beban bagi keluarga dan pemerintah serta dapat menjadi aset Negara yang berharga dalam proses pembangunan (Thalib, Ramadhani, Prostodonsia, Kedokteran, \& Universitas, 2015)

Status kesehatan lansia yang menurun seiring dengan bertambahnya usia akan mempengaruhi kualitas hidup lansia (Kiik, Sahar, \& Permatasari, 2018). Kualitas hidup (Quality of life) merupakan persepsi individu secara keseluruhan mengenai kebahagiaan dan kepuasan dalam kehidupan dan lingkungan sekitar dia hidup (Sari \& Pramono, 2014). Pada umumnya lanjut usia mengalami keterbatasan, sehingga kualitas hidup pada lanjut usia mengalami penurunan (Yuliati, Baroya, Ririanty, 2014). Rendahnya kualitas hidup lansia akan berdampak pada kesejahteraan lansia (Hayulita, bahasa, sari, 2018).

Kualitas hidup tidak hanya dipengaruhi oleh faktor-faktor psikologis dan sosial ekonomi, tetapi juga status gizi. Masalah gizi pada lansia perlu menjadi perhatian khusus karena dapat mempengaruhi status kesehatan, penurunan kualitas hidup, dan mortalitas. Gizi kurang maupun gizi lebih pada masa dewasa akhir dapat memperburuk kondisi fungsional dan kesehatan fisik (Sari dan Pramono, 2014). Kebiasaan makan yang tidak sehat dapat menyebabkan berbagai macam gangguan kesehatan dan mempengaruhi status gizi lansia yang akhirnya berdampak pada penurunan kualitas hidup. Makanan dan gizi dapat menjadi dimensi penting dalam pengukuran kualitas hidup. Status gizi yang kurang atau berlebih akan mempengaruhi kualitas hidup lansia (Nursilmi et al., 2017).

Data dari Dinas kesehatan Kabupaten Klaten yang mengalami masalah status gizi IMT di Kabupaten Klaten pada lansia pada bulan Januari-Desember 2018 secara keseluruhan di dapatkan pada lansia laki-laki sekitar 3.638 jiwa dan pada lansia wanita sekitar 3.368 jiwa (Profil kesehatan Dinas Kesehatan Klaten, 2018). Berdasarkan dari data hasil pendahuluan yang dilakukan oleh peneliti pada tanggal 2-11 september 2019 di 5 posyandu lansia di wilayah kerja puskesmas Jogonalan I di dapatkan data hasil dari 100 lansia yang mengikuti posyandu ditemukan lansia dengan status gizi kurang 36 orang (36\%), status gizi normal 44 orang (44\%), dan status gizi lebih 20 orang (20\%).

Status gizi lansia sangat dipengaruhi oleh proses menua. Proses penuaan sangat individual dan berbeda perkembangannya bagi setiap individu karena dipengaruhi oleh faktor internal dan eksternal. Asupan gizi dari makanan mempengaruhi proses menjadi tua karena seluruh aktivitas sel (metabolisme tubuh) memerlukan nutrien yang cukup selain faktor penyakit dan lingkungan (Fatmah, 2013). Bertambahnya usia bukan menjadi penghalang untuk mendapatkan asupan zat gizi yang cukup dan berkualitas. Pertambahan usia akan menimbulkan beberapa perubahan baik secara fisik maupun mental. Perubahan ini akan mempengaruhi kondisi seseorang dari aspek psikologis, fisiologis dan sosial ekonomi sebagian besar kebutuhan zat gizi para lansia 
mengalami penurunan. Masalah gizi pada lansia muncul dikarenakan perilaku makan yang salah, yaitu ketidakseimbangan antara konsumsi gizi dengan kecukupan gizi yang dianjurkan (Emmelia Ratnawati, 2017). Bagi lansia, pemenuhan kebutuhan gizi yang diberikan dengan baik dapat membantu dalam proses beradaptasi atau menyesuaikan diri dengan perubahan-perubahan yang dialaminya. Selain itu, dapat menjaga kelangsungan pergantian sel-sel tubuh sehingga dapat menjaga kesehatan fisik serta meningkatkan kualitas hidupnya (Rahmianti, Bahar, Yustini, 2014).

Kualitas hidup lansia dapat ditingkatkan melalui beberapa program seperti posyandu lansia, puskesmas keliling, senam lansia, penyuluhan dan perlu diberikannya jaminan kesehatan kepada lansia. Dengan terpenuhinya segala aspek tersebut maka kualitas hidup lansia yang baik dapat diwujudkan (Anbarasan, 2015). Dan dengan kebiasaan mengatur pola makan, gaya hidup yang baik menyebabkan seseorang mempunyai kualitas hidup yang baik, sedangkan kualitas hidup yang kurang dimiliki seseorang dengan kebiasaan yang dapat meningkatkan paparan penyakit (Nursilmi et al., 2017). Latar belakang ini mendasari peneliti tertarik melakukan penelitian dengan tema hubungan status gizi dengan kualitas hidup pada lansia di Puskesmas Jogonalan 1.

\section{METODE PENELITIAN}

Desain penelitian ini menggunakan kuantitatif korelasi dengan pendekatan Cross Sectional. Sampelnya adalah lansia yang melakukan pemeriksaan di Puskesmas Jogonalan I dengan 133 responden. Sampel diambil dengan consecutive sampling dengan kriteria inklusi yaitu lansia yang bersedia menjadi responden, lansia yang berusia 60-74 tahun, lansia yang dapat berkomunikasi dengan baik dan tidak mengalami gangguan pada pendengarannya, lansia yang dapat berdiri untuk dilakukan pengukuran berat badan dan tinggi badan dan dengan kriteria ekslusi yaitu lansia yang mengalami diare $\geq 5$ hari dan lansia yang mempunyai penyakit Diabetes Melitus . Dalam penelitian ini yang menjadi variabel independent adalah status gizi, dan variabel dependent adalah kualitas hidup lansia. Data dikumpulkan dengan menggunakan instrumen berupa pengukuran antropometri dengan IMT pengukuran berat badan dan tinggi badan dan kuesioner WHOQOL-BREF. Data yang terkumpul kemudian di sajikan dalam bentuk tabel dan selanjutnya dilakukan analisis dengan SPSS Uji Kendall's Tau dengan tingkat signifikan $\alpha 0,05$.

\section{HASIL DAN PEMBAHASAN}

Tabel 1 Rerata Usia Responden di Puskesmas Jogonlan 1 Tahun 2019 ( $\mathrm{n}=133$ )

\begin{tabular}{cccc}
\hline Variabel & Min & Max & Mean \pm SD \\
\hline Usia & 60 & 74 & $68,24 \pm 3,589$ \\
\hline
\end{tabular}

Tabel 1 di atas diketahui rerata usia responden pada penelitian ini adalah 68,24 tahun dan standar deviasi $\pm 3,589$. usia responden di Puskesmas Jogonalan 1 dalam penelitian ini berusia 60-74 tahun dengan rerata usia 68,24 tahun dengan standart deviasi sebesar 3,589.

Penelitian yang dilakukan oleh Fadillah, Suyatno, Nugraheni (2019) memaparkan usia dapat mempengaruhi kebutuhan gizi pada lansia dikarenakan lansia sedikit melakukan konsumsi lauk pauk yang mengandung protein hewani. Hal tersebut dikarenakan adanya perubahan fungsi fisiologis yang terjadi akibat proses penuaan pada lansia yang menyebabkan asupan sumber protein hewani seperti daging dan ikan menjadi berkurang, yaitu karena tanggalnya gigi lansia, yang juga menurunya kemampuan mengunyah makanan yang bertekstur keras dan alot. Kualitas hidup pada lansia terus menurun seiring dengan semakin bertambahnya usia. Pengaruh proses menua dapat menimbulkan berbagai masalah baik secara fisik, mental, serta perubahan kondisi sosial (Suwanmanee et al, 2012).

Penelitian (Indrayani dan Ronoatmodjo 2018) mengemukakan bahwa seiring dengan bertambahnya usia, maka akan terjadi beberapa perubahan pada lansia meliputi penurunan kondisi fisik, perubahan psikologis yang dipengaruhi oleh menurunnya kondisi fisik, kesehatan 
lansia yang semakin menurun serta kondisi lingkungan dimana lansia berada dan perubahan psikososial seperti menurunnya tingkat kemandirian serta psikomotor yang menyebabkan lansia mengalami suatu perubahan dari sisi aspek psikososial. Perubahan akibat proses menua baik perubahan fisik, perubahan mental, perubahan psikososial yang mengarah pada kemampuan lansia untuk melakukan aktifitas sehari-hari dan berpengaruh terhadap kualitas hidup lansia.

Pada penelitian ini usia dikendalikan dengan memilih usia 60-74 tahun karena semakin tua usia lansia maka akan berbeda status gizi dan kualitas hidupnya. Dan didapatkan pada penelitian ini rata-rata semakin tua usia lansia maka status gizi nya semakin berkurang dan kualitas hidup nya semakin buruk, karena dengan bertambahnya usia maka terjadi perubahan pada struktur dan fungsi tubuh yang dialami oleh lansia terjadi hampir diseluruh sistem tubuh. salah satu perubahan struktur dan fungsi terjadi pada sistem gastrointestinal. Perubahan beberapa aspek nutrisi, seperti indera penciuman dan rasa, kemampuan untuk mengunyah dan menelan, fungsi pencernaan dan usus merupakan faktor terkait penuaan dan pada akhirnya mempengaruhi kualitas hidupnya. Pada penelitian ini lansia dengan status gizi kurang mengalami keluhan tidak nafsu makan karena makanan yang tidak variatif dan juga karena penurunan indra penciuman, perasa, sulit menelan karena perubahan fisiologis pada sekresi saliva dan sulit mengunyah karena mengalami gigi tanggal/ompong.

\section{Distribusi Jenis Kelamin, Pekerjaan, Pendidikan Dan Status Pernikahan}

Tabel 2 Distribusi responden berdasarkan jenis kelamin, pekerjaan, pendidiakan dan status pernikahan di Puskesmas Jogonlan 1 Tahun 2019 ( $\mathrm{n}=133)$

\begin{tabular}{|c|c|c|}
\hline Variabel & $\begin{array}{c}\text { Frekuensi } \\
(\mathrm{n}=133)\end{array}$ & Prosentase \% \\
\hline \multicolumn{3}{|l|}{ Jenis Kelamin } \\
\hline 1. Laki-laki & 50 & 37,6 \\
\hline 2. Perempuan & 83 & 62,4 \\
\hline \multicolumn{3}{|l|}{ Status Pernikahan } \\
\hline 1. Kawin & 47 & 35,3 \\
\hline 2. Cerai Mati & 79 & 59,4 \\
\hline 3. Cerai Hidup & 7 & 5,3 \\
\hline \multicolumn{3}{|l|}{ Pekerjaan } \\
\hline 1. IRT & 58 & 43,6 \\
\hline 2. Petani & 38 & 28,6 \\
\hline 3. Wiraswasta & 34 & 25,6 \\
\hline 4. PNS & 4 & 2,3 \\
\hline \multicolumn{3}{|l|}{ Pendidikan } \\
\hline 1. Tidak Sekolah & 15 & 11,3 \\
\hline 2. SD & 83 & 62,4 \\
\hline 3. SMP & 28 & 21,1 \\
\hline 4. SMA & 7 & 5,3 \\
\hline \multicolumn{3}{|l|}{ Tinggal Dengan Siapa } \\
\hline 1. Sendiri & 60 & 45,1 \\
\hline 2. Keluarga & 73 & 54,9 \\
\hline \multicolumn{3}{|l|}{ Status Gizi } \\
\hline 1. Kurang & 41 & 30,8 \\
\hline 2. Normal & 47 & 35,3 \\
\hline 3. Lebih & 45 & 33,8 \\
\hline \multicolumn{3}{|l|}{ Kualitas Hidup } \\
\hline 1. Kurang baik & 70 & 52,6 \\
\hline 2. Baik & 63 & 47,4 \\
\hline
\end{tabular}


Tabel 2 menunjukkan distribusi responden didominasi responden perempuan sebanyak 62,4\%. Data distribusi responden menurut status pernikahan sebesar 59,4\% cerai mati. Data distribusi responden menurut pekerjaan sebesar 43,6\% IRT. Data distribusi responden menurut pendidikan sebesar $62,4 \%$ SD. Data distribusi responden menurut tinggal dengan siapa sebesar 54,9\% keluarga. Data distribusi responden menurut status gizi menunjukkan sebesar 35,3\% memiliki status gizi normal. Data distribusi responden menurut kualitas hidup lansia menunjukkan sebesar 52,6\% memiliki kualitas hidup buruk.

Jenis kelamin responden di wilayah kerja Puskesmas Jogonalan 1 dalam penelitian ini didominasi oleh responden perempuan sebesar $62,4 \%$, hal ini sejalan dengan penelitian yang dilakukan oleh HS (2012) memaparkan jenis kelamin mempunyai hubungan dengan kebutuhan gizi lansia karena Laki-laki cenderung membutuhkan gizi yang lebih banyak dibandingkan dengan perempuan untuk membantu proses metabolisme. Karena, laki-laki memiliki aktivitas fisik yang tinggi dan juga dipengaruhi oleh berat badan. Dimana tubuh pria lebih berat dibandingkan perempuan. Begitu juga untuk tinggi tubuh. Karena itulah, pria juga membutuhkan makanan yang lebih banyak dibandingkan dengan perempuan. Dari jumlah kalori, pria membutuhkan minimal 400 kalori lebih banyak dari pada perempuan, tergantung pada aktivitas.

Penelitian lain yang menguatkan temuan ini adalah penelitian yang dilakukan oleh Ardiani, Lismayanti, dan Rosnawaty (2014), menyimpulkan ada hubungan antara jenis kelamin dengan kualitas hidup lansia. Hasil analisis yang peneliti dapatkan bahwa lansia perempuan lebih banyak dibandingkan lansia laki-laki. Peneliti berasumsi, hal ini dikarenakan usia harapan hidup yang paling tinggi adalah pada perempuan. Kemudian berhubungan juga dengan pengaruh hormonal pada perempuan usia lanjut produktif dimana hormon estrogen mempunyai peran sebagai pelindung, sehigga menyebabkan angka harapan hidup perempuan lebih tinggi daripada laki-laki. Sedangkan pada laki-laki peran estrogen sangat sedikit, dan juga mempunyai beban kerja fisik yang lebih berat ditambah dengan perilaku merokok dan kebiasaan makan yang kurang berimbang.

Pada penelitian ini responden perempuan lebih banyak dijumpai dari pada laki-laki, sehingga kesempatan responden perempuan untuk dilakukan penelitian lebih besar. Lansia perempuan yang memiliki keluhan sakit baik akut maupun kronis lebih tinggi dibandingkan dengan lansia laki-laki. Pada penelitian ini rata-rata lansia laki-laki memiliki status gizi normal dan kualitas hidup baik dibandingkan dengan lansia perempuan, dikarenakan lansia laki-laki lebih banyak porsi makan nya tetapi mereka banyak melakukan aktivitas dibandingkan dengan lansia perempuan dan untuk kualitas hidup lansia laki-laki lebih baik dari perempuan karena lansia laki-laki lebih tinggi mempunyai hubungan sosial, kondisi kehidupan dan kesehatan di bandingkan lansia perempuan.

Status pernikahan lansia responden di wilayah kerja puskesmas jogonalan 1 sebagai besar sudah ditinggal pasangan hidupnya mati atau cerai mati sebanyak 59,4\%. Lansia yang hidup sendiri atau ditinggal oleh orang yang dicintai tanpa ada dukungan teman atau keluarga berdampak pada perubahan status gizinya, oleh karena itu guna memenuhi kebutuhannya dibutuhkan dukungan dari keluarga (Yuniarti dan Putri, 2019). Pasangan hidup lansia yang selalu berada disampingnya, membuat lansia memiliki teman bicara, teman curhat dan berkeluh kesah tentang kebahagiaan maupun kesedihan, sehingga dengan koping lansia yang positif serta dukungan positf dari pasangan akan meningkatkan kualitas hidup lansia (Astuti, 2019).

Pada penelitian ini paling banyak lansia dengan status pernikahan cerai mati atau ditinggal pasangan nya meninggal dunia dan lebih banyak dialami oleh lansia perempuan. Penelitian ini sesuai dengan data BPS 2015 dan menunjukkan bahwa usia harapan hidup perempuan lebih 
tinggi dibandingkan laki-laki sehingga persentase lansia perempuan yang berstatus cerai mati lebih banyak dibandingkan lansia laki-laki. Kehilangan pasangan hidup yang terjadi pada lansia pada umumnya disebabkan oleh kematian. Kehilangan pasangan hidup karena kematian merupakan peristiwa yang dapat menimbulkan stress atau gangguan psikologis pada lansia.

Gangguan psikologis ini dapat timbul karena banyak nya kegiatan yang sebelumnya dapat dibagi atau dilakukan bersama pasangan yang kemudian harus dilakukan sendiri, seperti membahas tentang masa depan anak, masalah ekonomi rumah tangga atau tentang hubungan sosial. Pada penelitian ini lansia yang memiliki status gizi kurang dengan cerai mati atau ditinggal pasangan nya meninggal dunia otomatis mempunyai perasaan kesepian sehingga menyebabkan nafsu makan berkurang yang berdampak pada status gizinya, dan mempunyai kualitas hidup yang buruk karena tidak ada nya dukungan dari pasangan nya atau orang yang dicintai nya sehingga dapat mempengaruhi kualitas hidupnya.

Variabel pekerjaan semua responden sudah tidak bekerja. Hal ini dapat disebabkan karena usia responden yang sudah tidak produktif dalam bekerja, tetapi riwayat pekerjaan sebelumnya rata-rata responden IRT sebesar 43,6\%. Penelitian yang dilakukan Hyun \& Lee (2014) mengenai status gizi lansia dan faktor resiko malnutrisi pada lansia yang tinggal di perkotaan dengan penghasilan rendah. Faktor utama yang mempengaruhi malnutrisi untuk lansia berpenghasilan rendah adalah kehilangan nafsu dan kesulitan dalam persiapan makanan (Hyun \& Lee, 2014).

Penelitian yang dilakukan oleh Ardiani, Lismayanti, dan Rosnawaty (2014), memaparkan bahwa terdapat hubungan antara pekerjaan dengan kualitas hidup lansia. Hasil analisis yang peneliti dapatkan menunjukan bahwa lansia lebih banyak sudah tidak bekerja. Peneliti berasumsi, hal ini dikarenakan umumnya ditunjang dengan kondisi kesehatan yang tidak memungkinkan mereka untuk bekerja. Namun, tidak sedikit juga lansia masih bekerja. Hal itu dikarenakan banyak alasan antara lain secara fisik dan mental masih mampu dan kuat bekerja, dan alasan terbanyak yaitu karena desakan ekonomi, yang mana untuk menghidupi keluarga, anak, dan cucu yang masih tinggal dengan lansia, karena anaknya pun berada dalam serba kekurangan.

Pada penelitian variabel pekerjaan ini semua lansia sudah tidak bekerja. Karena untuk lansia yang masih bekerja dan sudah tidak bekerja otomatis status gizi dan kualitas hidup nya berbeda, tetapi untuk riwayat pekerjaan sebelumnya rata-rata lansia tersebut IRT karena didapatkan banyak responden perempuan. Pekerjaan dengan tingkat penghasilan yang berbeda dapat mempengaruhi status gizi dan kualitas hidup lansia. Perbedaan pada penelitian ini menyebabkan adanya perbedaan pada kebiasaan makan, kebiasaan makan akan mempengaruhi status gizi. Lansia yang tidak bekerja cenderung mudah merasa cemas dan ketakutan serta adanya ketergantungan dalam hal ekonomi. Dan cenderung lansia yang sudah tidak bekerja memiliki kualitas hidup yang buruk dibandingkan lansia yang masih bekerja karena lansia yang masih bekerja memiliki penghasilan, kegiatan, dukungan sosial dari teman sehingga dapat mempengaruhi kualitas hidup lansia.

Tingkat pendidikan hasil penelitian di wilayah kerja Puskesmas Jogonalan 1 ini sebagian besar berpendidikan SD atau tidak tamat SD sebanyak 62,4\%. Bahri, Putra dan Suryanto (2017) dalam penelitiannya Tingkat pendidikan yang dimiliki oleh lansia menjadi bekal lansia dalam menerima dan memahami informasi tentang asupan gizi, baik melalui media informal misalnya penyuluhan oleh petugas kesehatan maupun dari sumber non formal misalnya melalui teman, buku-buku, dan media lainnya. 
Pada penelitian ini tingkat pendidikan lansia di Puskesmas Jogonalan 1 relatif masih rendah. Rata-rata responden berpendidikan SD, hal ini disebabkan pada saat responden masih usia sekolah, hanya orang-orang tertentu saja yang dapat berpendidikan yang lebih tinggi pada saat itu. Tingkat SD paling tidak bisa membaca sehingga lansia dapat memperoleh informasi kesehatan dari leaflet ataupun penyuluhan-penyuluhan. Tingkat pendidikan turut menentukan mudah atau tidaknya seseorang dalam memahami pengetahuan yang diperoleh, pada umumnya semakin tinggi pendidikan seseorang makin baik pula pengetahuannya. Rendahnya tingkat pendidikan lansia dapat mempengaruhi aksesibilitas ke fasilitas kesehatan. Pendidikan merupakan salah satu faktor yang mempengaruhi kualitas hidup lansia, karena dengan tingginya jenjang pendidikan maka pengetahuan seseorang akan sadar gizi berpengaruh terhadap kualitas hidup.

Tempat tinggal lansia temuan penelitian ini lansia lebih banyak tinggal bersama dengan keluarga. Lingkungan tempat tinggal memiliki dampak besar bagi kesehatan lansia. Lingkungan tempat tinggal yang berbeda mengakibatkan perubahan peran lansia dalam menyesuaikan diri (Yuliati et al, 2014). Berdasarkan penelitian didapatkan bahwa status gizi lansia yang tinggal bersama keluarga sangat baik. Keluarga menyiapkan makanan yang sesuai dengan lansia. Salah satu faktor yang mempengaruhi adalah faktor psikis yaitu motivasi diri, perasaan dan emosi serta dukungan keluarga (Zuraida et al, 2014).

Pada penelitian ini paling banyak di dapatkan lansia tinggal bersama keluarga. Rata-rata lansia yang tinggal bersama keluarga nya memiliki status gizi yang baik dan kualitas hidup yang baik, karena dengan lansia tinggal bersama keluarga mempunyai dukungan dari keluarga. Lansia yang tinggal bersama keluarga otomatis kebutuhan nutrisi nya sangat diperhatikan dibandingkan dengan lansia yang tinggal sendirian. Dukungan keluarga termasuk dalam faktor pendukung (supporting factors) yang dapat mempengaruhi perilaku dan gaya hidup lansia. Keluarga memiliki peranan yang penting dalam konsep sehat sakit anggota keluarganya yang sudah lansia, dimana keluarga merupakan sebuah sistem pendukung yang memberikan perawatan langsung terhadap anggota keluarganya yang sakit sehingga berdampak pada fisik, psikologis, sosial, dan lingkungan yang akan berpengaruh pada peningkatan kualitas hidup lansia.

Temuan penelitian ini status gizi lansia yaitu dengan status gizi normal 35\%, status gizi lebih sebesar 33,8\% dan status gizi kurang sebesar 30,8\%. Responden lansia yang memiliki status gizi normal dan status gizi lebih, hal ini dikarenakan lansia tinggal dengan keluarganya sehingga dapat membantu dalam memenuhi nutrisi nya dan adanya motivasi diri dari keluarga nya dibandingkan lansia yang tinggal sendirian. Berdasarkan penelitian didapatkan bahwa status gizi lansia yang tinggal bersama keluarga sangat baik. Keluarga menyiapkan makanan yang sesuai dengan lansia. Salah satu faktor yang mempengaruhi adalah faktor psikis yaitu motivasi diri, perasaan dan emosi serta dukungan keluarga (Zuraida et al , 2014).

Dan untuk status gizi lebih hal ini dikarenakan lansia sudah tidak bekerja lagi sehingga sedikit melakukan aktivitas fisik. Dan untuk status gizi kurang pada penelitian ini lansia mengatakan keluhan tidak nafsu makan karena makanan yang tidak variatif dan juga karena penurunan indra penciuman, perasa, sulit menelan karena perubahan fisiologis pada sekresi saliva dan sulit mengunyah karena mengalami gigi tanggal/ompong dan lansia mengatakan mereka tinggal sendirian jadi merasa kesepian karena tidak adanya motivasi dan dukungan makan terhadap dirinya. Penelitian ini sejalan dengan Emmelia ratnawati, (2017) mengatakan masalah gizi pada lansia muncul dikarenakan perilaku makan yang salah dan tidak nafsu makan, sehingga ketidakseimbangan antara konsumsi gizi yang dianjurkan. Sementara Qurniawat, (2018) mengatakan Perilaku makan akan mempengaruhi zat-zat gizi dan nutrisi yang masuk 
kedalam tubuh untuk proses peningkatan kualitas hidupnya yang akan berpengaruh terhadap kondisi status gizi serta proses penuaan yang sehat.

Kualitas hidup lansia hasil penelitian ini 52,6\% kurang baik dan kualitas hidup baik sebesar $47,4 \%$ lansia. Lansia yang memiliki status gizi kurang cenderung memiliki kualitas hidup yang kurang baik dibandingkan dengan lansia yang memiliki status gizi normal dan lebih. Kualitas hidup lansia yang baik dapat dilihat dari status gizi subjek dengan kategori gizi baik. Pemenuhan kebutuhan gizi yang baik dapat membantu proses beradaptasi dengan perubahan yang dialami dan dapat menjaga kelangsungan pergantian sel-sel tubuh sehingga dapat memperpanjang usia. Pada penelitian ini lansia yang memiliki kualitas hidup baik yaitu lansia yang selalu melakukan aktivitas fisik lima kali perminggu, sering melakukan rekreasi, tidak memiliki rasa takut untuk melakukan segala aktivitas, dan juga tidak memiliki gangguan pendengaran dan penglihatan. Penelitian yang dilakukan oleh (Nursilmi et al., 2017).mengatakan kualitas hidup yang baik dimiliki seseorang dengan kebiasaan mengatur pola makan dan gaya hidup yang baik sedangkan kualitas hidup yang kurang dimiliki seseorang dengan kebiasaan yang dapat meningkatkan paparan penyakit.

Tabel 3 Hubungan Status Gizi dengan Kualitas Hidup pada Lansia di Puskesmas Jogonalan I tahun 2019 ( $\mathrm{n}=133)$

\begin{tabular}{|c|c|c|c|c|c|c|c|c|}
\hline \multirow{3}{*}{$\begin{array}{c}\text { Status } \\
\text { Gizi }\end{array}$} & \multicolumn{6}{|c|}{ Kualitas Hidup Lansia } & \multirow{3}{*}{$\begin{array}{c}p \\
\text { value }\end{array}$} & \multirow{3}{*}{$r$} \\
\hline & \multicolumn{2}{|c|}{ Buruk } & \multicolumn{2}{|c|}{ Baik } & \multicolumn{2}{|c|}{ Total } & & \\
\hline & $\mathrm{f}$ & $\%$ & $\bar{F}$ & $\%$ & $\mathrm{f}$ & $\%$ & & \\
\hline $\begin{array}{c}\text { Renda } \\
h\end{array}$ & 40 & 57,1 & 1 & 1,6 & 41 & 47,4 & & \\
\hline $\begin{array}{c}\text { Norma } \\
1\end{array}$ & 18 & 25,7 & 29 & 46,0 & 47 & 27,8 & 0,00 & $0,529 *$ \\
\hline Lebih & 12 & 17,1 & 33 & 52,4 & 45 & 24,8 & & \\
\hline Total & 70 & 100,0 & 63 & 100,0 & 133 & 100,0 & & \\
\hline
\end{tabular}

Tabel 3 menunjukkan analisa bivariat nilai $p$ value $0,000<0,05$, sehingga Ha diterima dan Ho ditolak, artinya bahwa ada hubungan yang signifikan antara status gizi dengan kualitas hidup lansia di Puskesmas Jogonalan 1. Nilai koefisien korelasi antar variabel dalam analisis data diperoleh hasil 1.000, artinya tingkat keeratan hubungan antar variabel memiliki hubungan yang sempurna (Sarwono, 2015). Hasil $\left(\mathrm{r}=0,529^{*}\right)$, menunjukkan hubungan yang positif artinya semakin baik status gizi lansia maka semakin baik juga kualitas hidup lansia di Puskesmas Jogonalan 1.

Analisis hubungan status gizi dengan kualitas hidup lansia diperoleh temuan nilai $p$ value $0,000<0,05$, sehingga Ha diterima dan Ho ditolak, artinya ada hubungan yang signifikan antara status gizi dengan kualitas hidup pada lansia di Puskesmas Jogonalan 1. Nilai koefisien korelasi antar variabel dalam analisis data diperoleh hasil 1.000, artinya tingkat keeratan hubungan antar variabel memiliki hubungan yang sempurna (Sarwono, 2015). Penelitian yang dilakukan oleh Aulia, Rahmiwati, Sitorus, (2017) menunjukkan data mayoritas lansia rata-rata berada pada kategori status gizi tidak normal. Hasil analisis didapatkan hubungan yang signifikan antara status gizi dengan kualitas hidup, dari hasil analisis penelitian diketahui status gizi menjadi faktor paling dominan dalam mempengaruhi kualitas hidup, lansia yang memiliki status gizi normal lebih cenderung untuk memiliki kualitas hidup yang baik 20 kali dibandingkan dengan lansia yang status gizinya tidak normal. Penurunan fungsi fisiologis pada lansia merupakan hal yang terjadi secara alami seiring pertambahan usia, perubahan-perubahan fungsi fisiologis pada lansia ini dapat menyebabkan penurunan asupan makanan yang berakibat pada penurunan status gizi.

Sejalan dengan penelitian Astuti, (2012) menyimpulkan terdapat hubungan yang signifikan antara status gizi lansia dengan kualitas hidup lansia $(\mathrm{p}=0,002)$, didapatkan hasil bahwa geriatri 
mempunyai status gizi baik memiliki kemungkinan untuk mempunyai kualitas hidup 16 kali lebih besar dari pada lansia dengan status yang tidak baik $(O R=15,556)$. Penelitian yang dilakukan oleh Labiibah (2015), didapatkan hubungan yang signifikan antara status gizi dan kualitas hidup lansia, dengan begitu dapat diasumsikan jika status gizi lansia semakin normal, maka kualitas hidupnya akan semakin baik pula. Sebaliknya, semakin status gizinya malnutrisi, maka akan semakin tidak baik pula kualitas hidupnya.

Pada penelitian ini ditemukan 1,6\% pada lansia laki-laki yang memiliki status gizi kurang dengan kualitas hidup baik, hal ini dikarenakan responden tersebut mempunyai nilai tinggi pada kualitas hidup domain hubungan sosial dan domain kondisi psikologi, Abidin (2013), mengungkapkan bahwa Lansia laki-laki memiliki kepuasan yang lebih tinggi dalam beberapa aspek yaitu hubungan personal, pelayanan sosial, kondisi kehidupan dan kesehatan. Sementara ditemukan $25,7 \%$ pada lansia yang memiliki status gizi normal dengan kualitas hidup buruk, hal ini dikarenakan lansia tersebut rata-rata memiliki nilai rendah pada kualitas hidup domain hubungan sosial dan domain kondisi psikologi, lansia yang memiliki status gizi normal tinggal bersama keluarga sehingga untuk hubungan sosial mereka kurang bersosialisasi, kegiatan seharihari mereka hanya dihabiskan di dalam rumah saja.

Temuan penelitian ini 52,4\% pada lansia yang memiliki status gizi lebih dengan kualitas hidup baik, hal ini ditemukan pada lansia menengah keatas, karena semua kebutuhan mereka terpenuhi sehingga untuk status gizinya sangat terpenuhi tetapi mereka melakukan aktivitas sedikit karena kebutuhannya di bantu oleh keluarga sehingga memiliki status gizi yang berlebih, dan rata-rata responden dengan status gizi lebih memiliki nilai yang tinggi pada domain kesehatan fisik dan domain kondisi lingkungan. (Nursilmi et al., 2017)memaparkan terdapat hubungan positif antara status gizi dengan kualitas hidup domain kesehatan fisik dan lingkungan. Status gizi kurang ataupun lebih dapat mengakibatkan keterbatasan dalam aktivitas lansia sehingga mempengaruhi kualitas hidup lansia domain kesehatan fisik. Penyebab tidak langsung masalah gizi adalah faktor lingkungan, pendapatan, dan ketersediaan informasi sehingga status gizi pada lansia berhubungan dengan kualitas hidup domain lingkungan.

Pada penelitian ini rata-rata kualitas hidup lansia memiliki nilai rendah pada kualitas hidup domain kesehatan fisik dan domain kondisi lingkungan. Karena lansia mengalami kemunduran fisik sehingga lansia mengeluh sering sakit. pemeliharaan usia lanjut harus ditunjukkan dengan menjaga agar tetap hidup sehat dan produktif secara sosial dan ekonomi sesuai dengan martabat kemanusiaan. Pemerintah dalam hal ini berkewajiban menyediakan fasilitas kesehatan bagi kelompok usia lanjut. Salah satu upaya yang disediakan untuk pemantauan kesehatan kelompok usia lanjut meningkat kualitas hidup lansia yaitu dengan adanya posyandu lansia (POKSILA). Posyandu lansia adalah suatu wadah pelayanan bagi usia lanjut I masyarakat, dengan menitik beratkan pada upaya promotif dan preventif, serta tidak mengabaikan upaya kuratif dan rehabilitatif. Pembentukan posyandu lansia yaitu untuk meningkatkan derajat kesehatan lansia dan mutu pelayanan kesehatan lansia di masyarakat. Kegiatan yang dilakukan di posyandu lansia meliputi Menimbang berat badan dan mengukur tinggi badan, lalu dihitung Indeks Massa Tubuh (IMT) untuk mengetahui status gizi lansia, Memberikan penyuluhan tentang gizi, pola hidup sehat, dan kesehatan lansia. (kusumawardhani dan Andanawarih, 2018).

Bagi lansia, pemenuhan kebutuhan gizi yang diberikan dengan baik dapat membantu dalam proses beradaptasi atau menyesuaikan diri dengan perubahan-perubahan yang dialaminya. Selain itu, dapat menjaga kelangsungan pergantian sel-sel tubuh sehingga dapat menjaga kesehatan fisik serta meningkatkan kualitas hidupnya. Jika asupan nutrisi cukup maka lansia akan sehat dan kualitas hidup lansia akan sejahtera dan sebaliknya, jika asupan nutrisi lansia kurang maka lansia tidak sehat dan kualitas hidup lansia tidak sejahtera.

\section{SIMPULAN DAN SARAN}

Kesimpulan yang diperoleh dari penelitian Ada hubungan yang signifikan antara status gizi dengan kualitas hidup pada lansia di Puskesmas Jogonalan 1, dengan $p$ value $0,000<0,05$ dimana status gizi yang baik maka baik pula kualitas hidup pada lansia. Puskesmas diharapkan dapat meningkatkan pelaksanaan program-program kesehatan lansia seperti posyandu lansia 
guna meningkatkan status gizi lansia, mengidentifikasi masalah gizi lansia dan kualitas hidup lansia dan dilakukan kunjungan ke keluarga untuk memberikan dukungan kepada keluarga dalam memotivasi dan membantu dalam meningkatkan status gizi dan kualitas hidup lansia.

\section{DAFTAR PUSTAKA}

Abidin, A.Y., Setyoadi., Ahsan. (2013). Hubungan Peran Kader Kesehatan Dengan Tingkat Kualitas Hidup Lansia. Jurnal Ilmu Keperawatan Volume 1 Nomor 2 hal 183-192

Anbarasan, S. S. (2015). Gambaran Kualitas Hidup Lansia Dengan Hipertensi Di Wilayah Kerja Puskesmas Rendang Pada Periode 27 Februari Sampai 14 Maret 2015. Intisari Sains Medis, $4(1), 113$.

Ardiani, H., Lismayanti, L., Rosnawaty, R. (2014). Faktor-Faktor Yang Berhubungan Dengan Kualitas Hidup Lansia Di Kelurahan Mugarsari Kecamatan Tamansari Kota Tasikmalaya. Journal of Psychiatry 47 (3), hal 42-50

Astuti, A. D. (2019). Status Perkawinan Meningkatkan Kualitas Hidup Lansia Di PSTW Sinta Rangkang Tangkiling Kalimantan Tengah. Jurnal Keperawatan dan Kesehatan Masyarakat, Volume 8 Nomor 1, Halaman 1-8, p-ISSN 2252-8865 e-ISNN 2598-4217

Astuti, F. A.A. (2012). Hubungan Status Gizi Dengan Kualitas Hidup Geriatri Di Posyandu Lansia Ngudi Sehat Bibis Baru Nusukan Banjarsari Surakarta. Naskah Publikasi Fakultas Kedokteran UMS 2012

Aulia, M., Rahmiwati, A., Sitorus, R. J. (2017). Hubungan Status Gizi Terhadap Kualitas Hidup Lansia Di Panti Sosial Tresna Werdha Warga Tama Indralaya. Jurnal Ilmu Kesehatan Masyarakat, Volume 8 Nomor 3, Halaman 208-

Bahri, A. S., Putra, F.A., Suryono, M. S. (2017). HUBUNGAN ANTARA TINGKAT PENGETAHUAN ASUPAN GIZI LANSIA DENGAN STATUS GIZI DI POSYANDU LANSIA SEDYOWARAS RW IV KELURAHAN SUMBER SURAKARTA. Jurnal Ilmu Keperawatan Indonesia. volume 10 nomor 1

Dinas Kesehatan Kabupaten Klaten. (2018). Profil Kesehatan Kabupaten Klaten 2018. Klaten: Dinkes.

Emmelia, R. (2017). Asuhan Keperawatan Gerontik. Yogyakarta: Penerbit Pustaka Baru Press

Fadillah, A. D., Suyatno., Nugraheni, S. H. (2019). Faktor-faktor yang berhubungan dengan kesesuaian praktik gizi pada lansia berdasarkan 10 pesan gizi seimbang. Jurnal Kesehatan Masyarakat (e-journal) volume 7 nomor 4 hal 708-719 (ISSN: 2356-3346).

Fatmah. (2010). Gizi Usia Lanjut. Jakarta: Erlangga.

Hayulita, S., Bahasa, A., Sari, A. N. (2018). Faktor Dominan Yang Berhubungan Dengan Kualitas Hidup Lansia. Jurnal Volume 5, Nomor 2.

HS, I. (2012). Hubungan Faktor-Faktor Yang Mempengaruhi Kebutuhan Gizi Dengan Status Gizi Lanjut Usia Di UPT D Rumoh Sejahtera Geunaseh Sayang Banda Aceh. Idea Nursing Journal, Vol III No 2, ISSN: 2087-2879 Hal 51-62.

Hyun, H.S., Lee, I., (2014). Nutritional Status and Risk Factors for Malnutrition in Lowincome Urban Elders. J Korean Acad Nurs Vol.44 No.6, 708-716. Diakses dari http://dx.doi.org/10.4040/jkan.2014.44.6.708 (14 November 2015)

Indrayani, I., Ronoatmodjo, S. (2018). Faktor-Faktor Yang Berhubungan Dengan Kualitas Hidup Lansia Di Desa Cipasung Kabupaten Kuningan. Jurnal Kesehatan Reproduksi, 9(1), 
$69-78$.

Khofifah, Siti, N. (2016). Keperawatan Gerontik.

Kiik, S. M., Sahar, J., \& Permatasari, H. (2018). Peningkatan Kualitas Hidup Lanjut Usia (Lansia) Di Kota Depok Dengan Latihan Keseimbangan. Jurnal Keperawatan Indonesia, 21(2), 109-116.

Kusumawardani, D. \& Andanawarih, P. (2018). Peran posyandu lansia terhadap Kesehatan lansia di perumahan Bina Griya Indah Kota Pekalongan. Jurnal Siklus Volume 7 Nomor 1 Halaman 273-277, p-ISSN: 2089-6778, e-ISSN: 2549-5054.

Labiibah, M. (2015). Hubungan Antara Status Gizi Dengan Kualitas Hidup Lansia Di Posyandu Lansia Di Kecamatan Sanden Bantul. Naskah Publikasi Fakultas Kedokteran UMS 2015.

Nursilmi., Kusharto, C. M., \& Dwiriani, C. M. (2017). HUBUNGAN STATUS GIZI DAN KESEHATAN DENGAN KUALITAS Relationship Nutritional and Health Status With Quality of Life of Elderly in Two Research Areas. Mkmi, 13(4), 369-379.

Qurniawat, Dessita. (2018). Hubungan Perilaku Makan Dan Status Gizi Pada Lansia Di Kecamatan Wates Kulon Progo. Jurnal Pendidikan Teknik Boga.

Rahmianti, Bahar, B., \& Yustini. (2014). Hubungan Pola Makan, Status Gizi, Dan Interaksi Sosial Dengan Kualitas Hidup Lansia Suku Bugis Di Kelurahan Sapanang Kabupaten Pangkep. 1-11.

Riyanti, P., Ratnawati, N. D., Kep, M., \& Kom, S. (2015). Hubungan Aktivitas , Status Emosional Dan Panti Werdha Bina Bhakti Serpong Tangerang Tahun 2015. (2), 1-19.

Sari, N. K., \& Pramono, A. (2014). of Nutrition College , Volume Halaman Online di: http://ejournal-s1.undip.ac.id/index.php/jnc. Journal of Nutrition College, 3(1), 83-89.

Suwanmanee, P., Areechon, N., Srisapoome, P., Taparhaudee, W. (2012). Effect of vitamin c on growth and disease resistance of nile tilapia larvae.

Thalib, B., Ramadhani, K. N., Prostodonsia, B., Kedokteran, F., \& Universitas, G. (2015). STATUS GIZI DAN KUALITAS HIDUP PADA LANSIA PENGGUNA Nutritional Status and Quality of Life in Elderly Used Complete Dentures in. Jurnal MKMI, 14, 44-49.

United Nasional. (2015). World Population http://www.un.org/en/development/desa/population/publications/pdf/ageing/WPA2015_Hig hlights.pdf. Diakses tanggal 10 Oktober 2017.

Yuliati, A., Baroya, N., Ririanty, M. (2014). Perbedaan Kualitas Hidup Lansia Yang Tinggal Di Komunitas dengan di Pelayanan Sosial Lanjut Usia. e-jurnal pustaka kesehatan, vol.2 no.1 hal.87-94

Yuniarti, T., Putri, A.P. (2019). Tingkat Pengetahuan Keluarga Dalam Pemberian Gizi Pada Lansia Cepogo Boyolali. Jurnal Riset Gizi Volume 7 Nomor 2. Hal 125-130.

Zuraida S, Dewi AP, Indriati G. Deskripsi Gaya Hidup Lansia Yang Tinggal Bersama Keluarga Dan di PSTW Khusnul Khotimah. 2014. http://lib.unri.ac.id/ojm/index.php/J OMPSIK/article/view/3392 Di unduh pada tanggal 12 Maret 2017. 